\title{
CD19 + CD23+ B cells, CD4 + CD25+ T cells, E-selectin and interleukin-12 levels in children with steroid sensitive nephrotic syndrome
}

\author{
Bilal Yildiz ${ }^{1 *}$, Nuran Cetin ${ }^{1}$, Nurdan Kural ${ }^{1}$ and Omer Colak ${ }^{2}$
}

\begin{abstract}
Background and methods: Soluble-lymphocyte subsets (sCD19+CD23+ B cells and sCD4 + CD25+ T cells), soluble-adhesion molecules (sE-selectin) and interleukin-12 (sIL-12) were assayed to evaluate the pathogenesis of steroid sensitive nephrotic syndrome in 48 patients diagnosed with steroid sensitive nephrotic syndrome (SSNS) in active (AS) and remission stages (RS).

Results: The ratios of soluble CD19 and sCD19+CD23 increased in patients with AS with respect to the patients with RS and controls $(p<0.05)$. Increased $s C D 19+C D 23$ ratios were preserved in the patients with RS when compared with the controls $(p<0.05)$. Moreover, the ratios of sCD4 + CD25 lymphocyte subsets were not significantly different among the groups. Similarly, serum slL-12 levels were not considerably disparate between the AS and RS. Serum sE-selectin levels were higher in the patients with AS relative to the controls $(p<0.01)$ and RS $(p<0.05)$. No significant correlations were noted between sE-selectin and lymphocyte subset ratios, serum sIL-12 and immunoglobulin levels. There was a positive correlation between sE-selectin, triglyceride $(r=0.757, p<0.0001)$ and cholesterol $(r=0.824, p<0.0001)$ levels in patients with the AS.
\end{abstract}

Conclusion: The present results indicate that the patients with SSNS appear to have abnormalities in SCD23 + CD19 + cells, defect in T regulatory cell activity, and injury in endothelial cells as indicated by the presence high sEselectin. These abnormalities might play a role in the pathogenesis of nephrotic syndrome. sIL-12 seems to have no role in pathogenesis of nephrotic syndrome reflecting normal Th1 response.

Keywords: Steroid sensitive nephrotic syndrome, sCD19 + CD23+ B cells, sCD4 + CD25+ T cells, sE-selectin, Interleukin-12

\section{Background}

Idiopathic nephrotic syndrome (INS) is the most prevalent kidney disease in children. Persistent immunogenic stimuli (such as viral infections, immunizations or allergens) might trigger nephrotic relapses in most of these patients. A primary immune disturbance is thought to be responsible for the pathogenesis of nephrotic syndrome in childhood. Various studies have attempted to identify potential abnormalities in lymphocyte subsets and they reported that during relapses, the subsets of $\mathrm{CD}_{4}^{+}$and $\mathrm{CD}^{+} \mathrm{T}$ cells expanded and levels of their cytokines increased (interleukin-2, IL-4 and interferon-) in the patients with nephrotic syndrome but reports regarding these measurements are conflicting [1-4]. Although steroid sensitive idiopathic nephrotic syndrome is a $\mathrm{T}$ lymphocyte mediated disorder, the pathogenetic role of B lymphocytes, effect of cytokines and vascular endothelial dysfunctions have not been well established in nephrotic syndrome. Therefore, in the present study we aimed to investigate the serum levels of solublelymphocyte subsets (sCD19+CD23+ B cells and sCD4 + CD25+ T cells), soluble-adhesion molecule (sE-selectin) and interleukin-12 (sIL-12) in patients with steroid sensitive nephrotic syndrome (SSNS).

\footnotetext{
* Correspondence: bilalyn@yahoo.com

'Department of Pediatric Nephrology, Faculty of Medicine, Eskisehir

Osmangazi University, Eskisehir, TR 26480, Turkey

Full list of author information is available at the end of the article
} 


\section{Materials and methods}

\section{Patients and control subjects}

We included 48 patients diagnosed with SSNS (32 boys, 16 girls; age range 30-202 months) in the present study. The control group contained 19 healthy individuals (12 boys, 7 girls; age range 27-190 months). The patients were divided into two groups: 28 (58.3\%) patients (20 boys, 8 girls) with active stage (AS) were grouped as Group 1 at the time of the diagnosis and $20(41.7 \%)$ patients (12 boys, 8 girls) with remission stage (RS) were grouped as Group 2. Blood samples were collected before steroid treatment in Group 1. The patients who did not response the steroid treatment excluded from the study. The patients in Group 2 were selected among the steroid sensitive nephrotic patients at remission stage. The mean duration of treatment with steroids was 28 weeks in Group 2. The patients showing complications of nephrotic syndrome including infection, thromboembolism, osteoporosis or receiving blood transfusions, immunosupresive agents such as cyclosporin and cyclophosphamide, angiotensin-converting enzyme inhibitors, non-steroidal anti-inflammatory drugs and anti-histamines were excluded from the present study.

Active stage was defined as increased urinary protein excretion $>40 \mathrm{mg} / \mathrm{m}^{2} / \mathrm{h}$ on timed sample or $>3+$ by dipstick for 3 consecutive days, spot albumin to creatinine ratio $>2 \mathrm{mg} / \mathrm{mg}$ and hypoalbuminaemia $<2.5 \mathrm{~g} / \mathrm{dl}$ ). Remission stage was defined as urinary protein excretion $<4 \mathrm{mg} / \mathrm{m}^{2} / \mathrm{h}$; nil or trace by dipstick on spot sample for 3 consecutive days.

\section{Study protocol}

The serum levels of E-selectine and IL- $12+\mathrm{p} 40$ were measured in the patients with AS before steroid treatment and in RS and in the controls using commercially available kits (BioSource International, Inc. Camarillo, California 93012 USA). Assays were performed using solid phase sandwich ELISA. The blood samples for sEselectine, and sIL- 12 were kept at $-70^{\circ} \mathrm{C}$ until the time of assay. Hemoglobin, erythrocyte count, platelet count, fibrinogen, total protein, cholesterol, triglycerides and albumin concentration were measured using standard laboratory methods.

Soluble peripheral lymphocyte subsets (CD3, CD4, CD8, CD19, sCD19 + CD23+ B cells and sCD4 + CD25+ $\mathrm{T}$ cells) were determined using double color flow cytometry (FACScan, Becton Dickinson, Sunnyvale, CA).

\section{Statistical analysis}

Data were analyzed using the SPSS for Windows package. All ranges quoted represent the standard error or deviation. Mann-Whitney $U$-test, $\mathrm{x}^{2}$ test and Spearman's test were used for analysis. A p value $<0.05$ was considered to be statistically significant.

\section{Ethics}

The current study was approved by the Research Ethics Committee of Eskişehir Osmangazi Medical Faculty, Eskişehir Osmangazi University. Informed consent was obtained from the parents or guardians of the patients and control subjects.

\section{Results}

Overall, the IgG levels decreased and IgM levels increased in patients with the AS with regard to the controls and RS. Serum IgE levels also augmented in patients with the AS with respect to RS the patients and the controls. Increased levels of IgE were sustained in the patients with the RS when compared with the controls. The immunoglobulin levels are illustrated in Table 1.

Subset ratios of the soluble CD3 and CD8 lymphocyte were similar in all study groups. Subset ratio of the soluble CD4 lymphocyte decreased in patients with the AS with regard the patients with RS. Moreover, the ratios of soluble CD19 and sCD19+CD23 increased as well in patients with AS in comparison to those with RS and controls (Table 2). Increased ratios of sCD19+CD23 were present in patients with RS when compared with the controls. In addition, sCD4 + CD25 lymphocyte subset ratios were not notably different between the groups (Table 2). The ratios of lymphocyte subsets are summarized in Table 2.

In addition, serum sIL-12 levels were not considerably different between the two groups (Table 3, Figure 1). Serum sE-selectin levels were higher in patients with AS than controls and RS (Table 3, Figure 1).

No significant correlations were noted between subset ratios of sE-selectin and lymphocyte, serum sIL-12 and immunoglobulin levels. There was a positive correlation between sE-selectin, triglyceride $(\mathrm{r}=0.757, \mathrm{p}<0.0001)$ and cholesterol $(\mathrm{r}=0.824, \mathrm{p}<0.0001)$ levels in Group 1 (Figure 2A and B).

\section{Discussion}

The pathogenesis of INS is currently considered an immune mediated disease with particularly $\mathrm{T}$ lymphocyte involvement. Impairment in the immunoglobulin isotype switching, which is strongly $\mathrm{T}$ lymphocyte-dependent has been shown [5]. Similar to earlier studies, we measured markedly decreased IgG levels and considerably increased IgM levels during AS. However, in the present study these alterations did not statically persist in the patients with RS. According to our results, the low IgG levels might be related $B$ cell disorders. We found low IgG levels and high CD19 and sCD19+CD23+ B cell ratio which reflects increase in number or activity of $\mathrm{B}$ cells (Table 2). These findings suggest a defect in production of IgG despite of increased number of B cells. 
Table 1 Serum Immunoglobulin (IgA, E, M and G) levels

\begin{tabular}{|c|c|c|c|c|}
\hline & Relapse $(n=28)$ (average + SD) & Remission $(n=20)($ average + SD) & Control $(n=19)$ & $\mathrm{p}$ \\
\hline \multirow[t]{3}{*}{$\lg A(m g / d l)$} & $93.9 \pm 38.8$ & $112.8 \pm 70.1$ & 134.5 & $\mathrm{p} 1=\mathrm{NS}$ \\
\hline & & & & $\mathrm{p} 2=\mathrm{NS}$ \\
\hline & & & & $\mathrm{p} 3=\mathrm{NS}$ \\
\hline \multirow[t]{3}{*}{$E(m g / d l)$} & $392.5 \pm 193.3$ & $133.4 \pm 32.8$ & $32.4 \pm 5.6$ & $\mathrm{p} 1=0.01$ \\
\hline & & & & $\mathrm{p} 2=0.001$ \\
\hline & & & & $\mathrm{p} 3=0.019$ \\
\hline \multirow[t]{3}{*}{ G (mg/dl) } & $316.9 \pm 237$ & $741.1 \pm 288.5$ & 1093 & $\mathrm{p} 1=0.002$ \\
\hline & & & & $\mathrm{p} 2=0.0001$ \\
\hline & & & & $\mathrm{p} 3=\mathrm{NS}$ \\
\hline \multirow[t]{3}{*}{$M(m g / d l)$} & $200.6 \pm 121.9$ & $121 \pm 54$ & 125 & $\mathrm{p} 1=0.002$ \\
\hline & & & & $\mathrm{p} 2<0.05$ \\
\hline & & & & $\mathrm{p} 3=\mathrm{NS}$ \\
\hline
\end{tabular}

p1: relapse vs. remission; p2: relapse vs. controls; p3: remission-controls.

The immune system deficiency in INS patients seems to be associated with excessive Th2 lymphocyte response. According to our findings, dominant $\mathrm{T}$ cell seems to be CD4+ T lymphocytes (Table 2). By contrast, Lama et al. report an imbalance of the CD4+/ CD8+ T lymphocytes distribution in favor of CD8+ $\mathrm{T}$ lymphocytes in relapse and remission in INS [6,7]. The existence of similar ratio of CD8+ T cells during in AS and RS and controls in the present study also suggested that CD8+ T lymphocytes were not dominant lymphocyte in patients with nephrotic syndrome. Our present observation is further supported by another study showing activation of the $\mathrm{NFkB}$ and c-maf transcription factors in CD4+ $\mathrm{T}$ lymphocytes during relapse [8]. Despite of increased $\mathrm{CD} 4+\mathrm{T}$ cells, sCD4 + CD25+ T cells were not increased in our patients with AS. The absence of increased $\mathrm{sCD} 4+\mathrm{CD} 25+\mathrm{T}$ cells might result in increased Th2 response. In fact, there were increased IgE levels and similar sIL-12 levels in AS, RS and the controls which showed Th2 cell response in our patients

Table 2 The soluble peripheral lymphocyte subsets ratios (\%)

\begin{tabular}{|c|c|c|c|c|}
\hline & $\begin{array}{c}\text { Relapse }(n=28) \\
\text { (average + SD) }\end{array}$ & $\begin{array}{l}\text { Remission }(n=20) \\
\quad \text { (average }+ \text { SD) }\end{array}$ & $\begin{array}{l}\text { Control }(n=19) \\
\text { (average + SD) }\end{array}$ & $p$ \\
\hline \multirow[t]{3}{*}{ CD3 } & $65.8 \pm 8.6$ & $71.6 \pm 6.3$ & $69.4 \pm 9.5$ & $\mathrm{p} 1=\mathrm{NS}$ \\
\hline & & & & $\mathrm{p} 2=\mathrm{NS}$ \\
\hline & & & & $\mathrm{p} 3=\mathrm{NS}$ \\
\hline \multirow[t]{3}{*}{ CD4 } & $30.8 \pm 6.3$ & $37.4 \pm 6.9$ & $35.8 \pm 7.4$ & $\mathrm{p} 1=0.019$ \\
\hline & & & & $\mathrm{p} 2=\mathrm{NS}$ \\
\hline & & & & $\mathrm{p} 3=\mathrm{NS}$ \\
\hline \multirow[t]{3}{*}{ CD8 } & $27.2 \pm 6.3$ & $27.6 \pm 7.1$ & $27.8 \pm 6.4$ & $\mathrm{p} 1=\mathrm{NS}$ \\
\hline & & & & $\mathrm{p} 2=\mathrm{NS}$ \\
\hline & & & & $\mathrm{p} 3=\mathrm{NS}$ \\
\hline \multirow[t]{3}{*}{ CD19 } & $20.3 \pm 10.1$ & $13.1 \pm 4.2$ & $12.8 \pm 6.1$ & $\mathrm{p} 1=0.028$ \\
\hline & & & & p2 $<0.05$ \\
\hline & & & & $\mathrm{p} 3=\mathrm{NS}$ \\
\hline \multirow[t]{3}{*}{$\mathrm{CD} 19+\mathrm{CD} 23$} & $13 \pm 9.7$ & $7.7 \pm 2.9$ & $5.0 \pm 2.3$ & $\mathrm{p} 1<0.05$ \\
\hline & & & & $\mathrm{p} 2=0.04$ \\
\hline & & & & $\mathrm{p} 3=0.046$ \\
\hline \multirow[t]{3}{*}{$\mathrm{CD} 4+\mathrm{CD} 25$} & $4.8 \pm 3.3$ & $3.7 \pm 1.4$ & $3.6 \pm 2.4$ & $\mathrm{p} 1=\mathrm{NS}$ \\
\hline & & & & $\mathrm{p} 2=\mathrm{NS}$ \\
\hline & & & & $\mathrm{p} 3=\mathrm{NS}$ \\
\hline
\end{tabular}


Table 3 Serum soluble IL-12 and E-selectin levels

\begin{tabular}{|c|c|c|c|c|}
\hline & $\begin{array}{c}\text { Relapse }(n=28) \\
\text { (average + SD) }\end{array}$ & $\begin{array}{c}\text { Remission }(n=20) \\
\text { (average + SD) }\end{array}$ & $\begin{array}{l}\text { Control }(n=19) \\
\text { (average + SD) }\end{array}$ & $p$ \\
\hline \multirow[t]{3}{*}{ Soluble IL-12 } & $277 \pm 185.8$ & $172.3 \pm 121.3$ & $202.3 \pm 45.3$ & $\mathrm{p} 1$ = NS \\
\hline & & & & $\mathrm{p} 2=\mathrm{NS}$ \\
\hline & & & & $\mathrm{p} 3=\mathrm{NS}$ \\
\hline \multirow[t]{3}{*}{ soluble E-selectin } & $134.8 \pm 67,47$ & $88.9 \pm 38,8$ & $100.2 \pm 37.6$ & $\mathrm{p} 1=0.007$ \\
\hline & & & & $\mathrm{p} 2<0.05$ \\
\hline & & & & p3 = NS \\
\hline
\end{tabular}

p1: relapse vs. remission; p2: relapse vs. controls; $\mathrm{p} 3$ : remission-controls.

with AS. Taken together, current study suggests that impairment of $\mathrm{T}$ regulatory cell $(\mathrm{sCD} 4+\mathrm{CD} 25+\mathrm{T}$ cell $)$ is present in nephrotic patients.

The B lymphocyte anomalies have not been well studied so far in children with nephrotic syndrome. Our study suggests that lymphocyte impairments in nephrotic syndrome do not seem to be limited to the $\mathrm{T}$ cell. We found that there were more B lymphocyte expansion in AS and RS than that of the controls as indicated with increased sCD19+CD23+ B lymphocytes and decreased IgG levels (Table 2). This finding prompted us to think that reduction of $\mathrm{B}$ lymphocytes could be preventing relapse ratios in patients with nephrotic syndrome. The therapeutic effects of rituximab, which suppresses B cell in the peripheral circulation as a chimeric anti-CD20 monoclonal antibody in nephrotic patients, supports our findings: (i) relapse rates following rituximab treatment may depend on the recovery of B-cells during the longterm course [9-11]. (ii) Moreover, rituximab might increase Treg frequency and number in patients with INS [12]. We did not find an increase in ratio of $\mathrm{sCD} 4+$ CD25+ T cells in patients with AS. Therefore, the increase of sCD4 + CD25+ Treg cells with rituximab supports our findings that Treg levels including sCD4 + CD25+ T cells is not enough in patients with nephrotic syndrome.

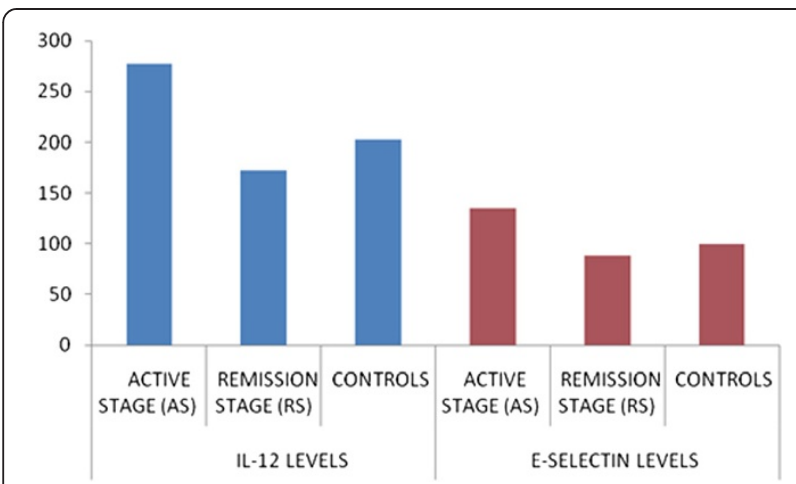

Figure 1 Serum levels of sIL-12 and sE-selectin. Serum levels of sIL-12 were similar in patients with active and remission stage and the controls. Serum E-selectin levels were higher in patients with active stage than remission satge and the controls.
On the other hand, sCD19+CD23+ B cells are related to allergic disorders [13]. sCD23 activation mediates IgE regulation, differentiation of $\mathrm{B}$ cells, activation of monocytes, and antigen presentation [14]. We found increased ratio of sCD19 + CD23+ B cells and serum IgE levels in AS and RS. These findings suggest that atopy and high IgE levels might not be related only with Th2 response in our patients. These findings also suggest that sCD19 $+\mathrm{CD} 23+\mathrm{B}$ cells and associated increased serum IgE could be related to relapse of nephrotic syndrome due to continued high ratio of sCD19 + CD23+ B cells and IgE levels in patients with remission.

The sIL-12 is shown to be a master regulator of Th1 response and cell-mediated immunity and sIL-12 can also up-regulate the production of vascular permeability factor in INS [15]. Therefore, sIL-12 has been implicated in the pathogenesis of INS $[15,16]$. Despite of the presence of in vitro data obtained from culture supernatants, there is no enough information on serum levels of sIL-12 as far as we are aware of. We found that serum sIL-12 levels were statistically similar in AS, RS and the controls. Also, there were no correlation between sIL-12 and lymphocyte sub-population and serum IgE levels in our study. According to these findings, sIL-12 seems to have no role in pathogenesis of nephrotic syndrome in our patients. Macrophages and monocytes produce sIL-12 as an early response to antigenic stimuli; therefore, we think that in vitro sIL-12 production of lipopolisaccaride stimulated peripheral blood mononuclear cells of INS patients could not be specific for nephrotic syndrome [17]. Indeed, GATA-3 (Th2-specific transcription factor) related Th2 cytokines are shown to negatively influence the production of sIL-12 in patients with INS $[18,19]$.

Adhesion molecules mediate the initial rolling of inflammatory cells along endothelial cells and platelets in response to pathological process. However, the role of adhesion molecules in the pathophysiology of nephrotic syndrome in children is not well known. Unlike other adhesion molecules, E-selectin is synthesized only by endothelial cells when activated by interleukin-1 or tumor necrosis factor- $[20,21]$. Thus, sE-selectin could 

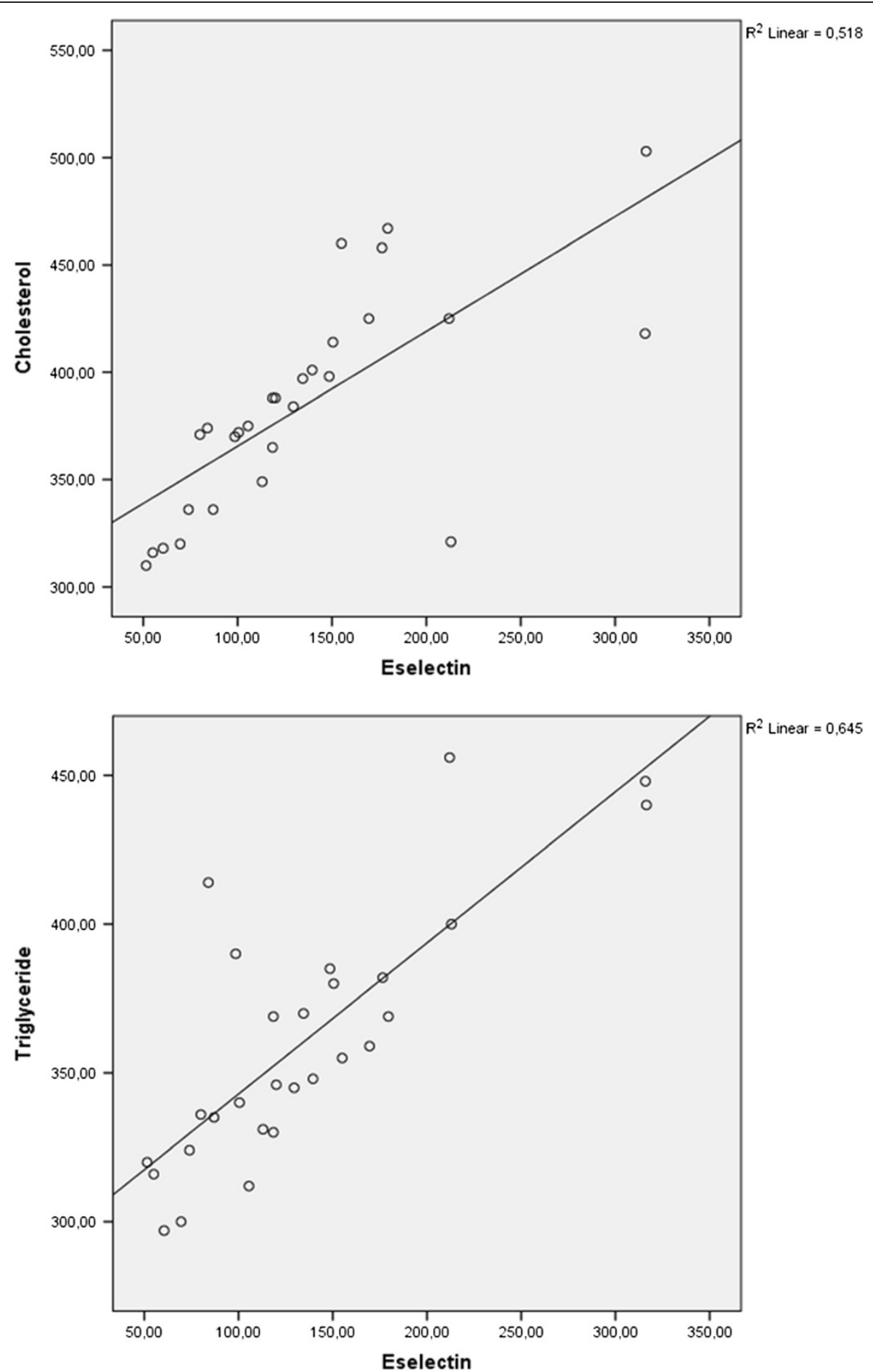

Figure 2 The positive correlations between E-selectin and triglyceride $(r=0.757, p<0.0001)$ and cholesterol $(r=0.824, p<0.0001)$ levels in nephrotic patients with active stage.

be a candidate marker for detection of endothelial injury in nephrotic syndrome. We found that sE-selectin levels were increased in patients with AS and it returned to normal after treatment. To our best knowledge, these findings are the first report on sE-selectin in children with nephrotic syndrome. We think that endothelial injury is not related to Th2 response and B lymphocyte due to lack of any relationship between $\mathrm{sE}$-selectin and 
lymphocyte subsets in our nephrotic patients with AS. These findings also cannot be explained with IL-12 levels which not increased in our patients with AS since IL-12 is demonstrated to increase the sE-selectin ligands on $\mathrm{T}$ lymphocytes [22]. The possible reason for increased E-selectin level might be the presence of hyperlipidemia which is reported to enhance the secretion of IL-6 and TNF-alpha [23]. On the other hand, hypercholesterolemia has been reported to increase superoxide anion production in endothelial cells [24]. In fact, we found that cholesterol and triglyceride levels were positively correlated with E-selectin levels in our patients. Hyperlipidemia seems to be associated with endothelial damage.

Glucocorticoids are of proven benefit in the treatment of proteinuria in patients with SSNS. We found that sE-selectin levels decreased but high ratios of sCD19 $+\mathrm{CD} 23+\mathrm{B}$ cells persisted with steroids therapy in patients with RS. Present findings suggest that steroid therapy can improve the endothelial cell functions but appears to fail to regulate expansion of B-cell in patients with RS. We think that expansion of the sCD19 + CD23+ B cells might contribute to the continuation of immune response in patients with RS. The implication of B-cells in SSNS remains to be investigated in detail in future studies.

\section{Conclusions}

In summary, present study suggests that patients with SSNS have abnormalities in their sCD23 + CD19+ B cells and show endothelial injury with high E-selectin levels. Furthermore, sIL-12 seems to have no role in pathogenesis of SSNS which reflects normal Th1 response. Present findings also implied that the patients with SSNS have $\mathrm{T}$ regulatory cell defect as indicated by normal sCD4 + CD25+ T cell ratio despite the increased immune response including high levels of IgM, IgE, CD19 and expanded sCD23 + CD19+ B cells.

\section{Competing interests}

The authors declare that they have no conflict of interests.

\section{Authors' contributions}

BY conceived of the study. BY and NK designed the study. OC made biochemical assay. BY, NC, OC and NK analyzed the data and critical revision of the manuscript for important intellectual content. BY drafted the manuscript and all authors read and approved of the manuscript.

\section{Author details}

'Department of Pediatric Nephrology, Faculty of Medicine, Eskisehir Osmangazi University, Eskisehir, TR 26480, Turkey. ${ }^{2}$ Department of Biochemistry, Faculty of Medicine, Eskisehir Osmangazi University, Eskisehir, TR 26480, Turkey.

Received: 17 January 2013 Accepted: 4 July 2013

Published: 6 July 2013

\section{References}

1. Herrod HG, Stapleton FB, Trouy RL, Roy S: Evaluation of T lymphocyte subpopulations in children with nephroticsyndrome. Clin Exp Immunol 1983, 52:581-585.

2. Yap HK, Cheung W, Murugasu B, Sim SK, Seah CC, Jordan SC: Th1 and Th2 Cytokine mRNA profiles in childhood Nephrotic Syndrome evidence for Increased IL-13 mRNA expression in relapse. J Am Soc Nephrol 1999, 10:529-537.

3. Schnaper HW: The immune system in minimal change nephrotic syndrome. Pediatr Nephrol 1989, 3:101-110.

4. Neuhaus TJ, Wadhwa M, Callard R, Barratt TM: Increased IL-2, IL-4, and interferon-gamma (IFN-) in steroid-sensitive nephrotic syndrome. Clin Exp Immunol 1995, 100:475-479.

5. Kemper MJ, Altrogge $H$, Ganschow R, Muller-Wiefel DE: Serum levels of immunoglobulins and IgG subclasses in steroid sensitive nephrotic syndrome. Pediatr Nephrol 2002, 17:413-417.

6. Lama G, Luongo I, Tirino G, Borriello A, Carangio C, Salsano ME: T-lymphocyte populations and cytokines in childhood nephrotic syndrome. Am J Kidney Dis 2002, 39:958-965.

7. Neuhaus TJ, Shah V, Callard RE, Barratt TM: T-lymphocyte activation in steroid-sensitive nephrotic syndrome in childhood. Nephrol Dial Transplant 1995, 10:1348-1352.

8. Sahali D, Pawlak A, Le Gouvello S, Lang P, Valanciute A, Remy P, Loirat C, Niaudet P, Bensman A, Guellaen G: Transcriptional and posttranscriptional alterations of IkappaBalpha in active minimal-change nephrotic syndrome. J Am Soc Nephrol 2001, 12:1648-1658.

9. Guigonis V, Dallocchio A, Baudouin V, Dehennault M, Hachon-Le Camus C, Afanetti M, Groothoff J, Llanas B, Niaudet P, Nivet H, Raynaud N, Taque S, Ronco $P$, Bouissou F: Rituximab treatment for severe steroid- or cyclosporine-dependent nephrotic syndrome: a multicentric series of 22 cases. Pediatr Nephrol 2008, 23:1269-1279.

10. Kamei K, Ito S, Nozu K, Fujinaga S, Nakayama M, Sako M, Saito M, Yoneko M, lijima K: Single dose of rituximab for refractory steroid-dependent nephrotic syndrome in children. Pediatr Nephrol 2009, 24:1321-1328.

11. Prytula A, lijima K, Kamei K, Geary D, Gottlich E, Majeed A, Taylor M, Marks SD, Tuchman S, Camilla R, Ognjanovic M, Filler G, Smith G, Tullus K: Rituximab in refractory nephrotic syndrome. Pediatr Nephrol 2010, 25:461-468.

12. Vallerskog T, Gunnarsson I, Widhe M, Risselada A, Klareskog L, Van Vollenhoven R, Malmstrom V, Trollmo C: Treatment with Rituximab affects both the cellular and the humoral arm of the immune system in patients with SLE. Clin Immunol 2007, 122:62-74.

13. Tantisira KG, Silverman ES, Mariani TJ, Xu J, Richter BG, Klanderman BJ, et al: FCER2: a pharmacogenetic basis for severe exacerbations in children with asthma. J Allergy Clin Immunol 2007, 120:1285-91.

14. Stone KD, Prussin C, Metcalfe DD: IgE, mast cells, basophils, and eosinophils. J Allergy Clin Immunol 2010, 125:S73-80.

15. Matsumoto K, Kanmatsuse K: Increased IL-12 release by monocytes in nephrotic patients. Clin Exp Immunol 1999, 117:361-367.

16. Lin CY, Chien JW: Increased interleukin-12 release from peripheral blood mononuclear cells in nephrotic phase of minimal change nephrotic syndrome. Acta Paediatr Taiwan 2004, 45:77-80.

17. Yoshimoto T, Kojima K, Funakoshi T, Endo Y, Fujita T, Nariuchi H: Molecular cloning and characterization of murine IL-12 genes. $\mathrm{J}$ Immunol 1996, 156:1082-1088.

18. Del Vecchio M, Bajetta E, Canova S, Lotze MT, Wesa A, Parmiani G, Anichini A: Interleukin-12: biological properties and clinical application. Clin Cancer Res 2007, 13:4677-85.

19. Komatsuda A, Wakui H, Iwamoto K, Togashi M, Masai R, Maki N, Sawada K: GATA-3 is upregulated in peripheral blood mononuclear cells from patients with minimal change nephrotic syndrome. Clin Nephrol 2009, 71:608-16.

20. Gearing AJH, Hemingway I, Piggott R, Hughes J, Rees AJ, Cashman SJ: Soluble forms of vascular adhesion molecules. E-selectin, ICAM-1 and VCAM-1: pathological significance. Ann NY Acad Sci 1992, 667:324-331.

21. Etter H, Althaus R, Eugster HP, Santamaria-Babi LF, Weber L, Moser R: IL-4 and IL-13 downregulate rolling adhesion of leukocytes to IL-1 or TNF-activated endothelial cells by limiting the interval of E-selectin expression. Cytokine 1998, 10:395-403.

22. Wagers AJ, Waters CM, Stoolman LM, Kansas GS: Interleukin 12 and interleukin 4 control $\mathrm{T}$ cell adhesion to endothelial selectins through 
opposite effects on \{alpha\}1,3-fucosyltransferase VII gene expression. J Exp Med 1998, 188:2225-2231.

23. Nishida Y, Yorioka N, Oda H, Yamakido M: Effect of lipoproteins on cultured human mesangial cells. Am J Kidney Dis 1997, 29:919-930.

24. Ohara Y, Peterson TE, Harrison DG: Hypercholesterolemia increases endothelial superoxide anion production. J Clin Invest 1993, 91:2546-51.

doi:10.1186/1824-7288-39-42

Cite this article as: Yildiz et al:: CD19 + CD23+ B cells, CD4 + CD25+ T cells, E-selectin and interleukin-12 levels in children with steroid sensitive nephrotic syndrome. Italian Journal of Pediatrics 2013 39:42.

\section{Submit your next manuscript to BioMed Central and take full advantage of:}

- Convenient online submission

- Thorough peer review

- No space constraints or color figure charges

- Immediate publication on acceptance

- Inclusion in PubMed, CAS, Scopus and Google Scholar

- Research which is freely available for redistribution 